\title{
Oilseeds Production Gaps under Cluster Frontline Demonstration in Kohima District of Nagaland, India
}

\author{
Imtisenla, Longma Yanger Pongen*, Temjennungsang, Khekali Sema, \\ K. Michael Pienyu, Zhiete and V. Akashe Zhimomi
}

Krishi Vigyan Kendra, Kohima, Nagaland-797109, India

*Corresponding author

\section{A B S T R A C T}

Ke y w o r d s
Cluster front line
demonstration,
Yield gap,
Extension gap,
Technology gap,
Technology index
Article Info
Accepted:
15 April 2020
Available Online:
10 May 2020

\section{Ke y w o r ds}

Cluster front line demonstration,

Yield gap,

Technology gap,

Technology index

Accepted:

15 April 2020

10 May 2020

\begin{abstract}
Oilseed production through Cluster Frontline demonstration is a strategy to increase oilseeds crops under various agro climatic condition of Kohima district in Nagaland. The study focused on horizontal dissemination of oilseed production during Kharif and Rabi period of 2017 to 2019. It observed a wide yield gap between achievable potential yield and demonstrated yield mainly due to extension gap and technology gap. The maximum extension gap on average was found in groundnut $(156 \mathrm{~kg} / \mathrm{ha})$, followed by sesamum $(172 \mathrm{~kg} / \mathrm{ha})$ and toria $(115$ $\mathrm{kg} / \mathrm{ha}$ ). The district has the potential to increase oilseed production in groundnut from $15.07 \%$ to $27.85 \%$, sesamum $(17.77 \%$ to $20.76 \%)$ and toria $(15.38 \%$ to $22.80 \%$ ), respectively. The technological index varied on average between 33.34 to $47.44 \%$. The incremental benefit: cost ratio on average varied between 2.53 to 3.33 indicating that selection of viable improved technologies would boost oilseed production substantially for doubling farmers' income.
\end{abstract}

\section{Introduction}

Oilseed crop occupies and important place in Indian Agriculture. It covers an area of 26 million hectare and produces 30 million tonnes of oilseeds of which 72 percent cultivated area fall under rainfed agriculture. India also ranks fourth in terms of oilseed production in the world. Vegetable oils which are an essential item for homes are produced from nine major oilseeds crops, among them Soybean (39\%), Groundnut (26\%) and Rapeseed-Mustard (24\%), contribute more than $88 \%$ of total oilseeds production in the country.

Despite its huge production India still is the largest importer of edible vegetables oil in the world, followed by china and USA. (GoI. 2018-19). 
Oilseeds producing areas are concentrated mainly in the central and southern parts of India in the states of Madhya Pradesh, Gujarat, Rajasthan, Andhra Pradesh and Karnataka.

Oilseed crop production for oil extraction is in a very nascent stage in kohima district of Nagaland. The district is bestowed with varied agro-climatic condition and soil type that enables to grow wide varieties of oilseeds viz. Mustard and rapeseed, sesamum, perilla, groundnut, sunflower which constitute the major oilseed of the district. The low productivity could be due to hilly terrain, lack of irrigation facilities, inferior quality seeds, rainfed cultivation and traditional farming system.

Therefore, to meet the demand of the growing population of the district, as projected in the vision 2020 document of the Krishi Vigyan Kendra. The strategy was to increase the acreage by $61 \%$ by year 2020 from the base year (2006-07) and increase the productivity from $0.88 \mathrm{MT} /$ ha to $1.78 \mathrm{MT} / \mathrm{ha}$ during the same period (Anonymous, 2008).

The implementation of Cluster Frontline Demonstration (CLFD) on oilseed in the year 2015 was a right initiative programme under the National Food Security Mission for boosting the oilseed production in the district.

A number of evidences pertaining to yield gap analysis under Frontline Demonstration had been carried out by Krishi Vigyan Kendras (KVKs) in different foodgrains like Pulses (Pongen, L.Y. et al., 2019), Oilseeds (Kanojia et al., 2019) and Cereals (Mubark and Shakoor, 2019).

Earlier studies estimated a wide productivity gaps in different crops. The present study also sought to assess the yield gap in oilseeds production system as no evidence of earlier studies is found for Kohima district, it aims not only to increase oilseeds production but also help improve the land and labour use efficiency, reduce production cost, introduce new genotypes seed varieties and doubling farmers' income.

\section{Materials and Methods}

The present study was carried out by Krishi Vigyan Kendra, kohima to understand the production gaps of oilseeds production. The data for the cropping period of Kharif $2017 \&$ 2018 and Rabi 2017-18 \& 2018-19 were identified for the study. Oilseed promotion during these periods covered an area of 110 ha, involving 158 farmers under 46 villages.

Cluster Front Line Demonstration (CFLD) on Oilseed was initiated during 2015-16 under the National Food Security Mission (NFSM) Programme and targeted three oilseeds crops viz. Toria (var. TS-36), Groundnut (G-2) and Sesamum (ST-1683) with respect to traditional local cultivar.

Before conducting the CFLD programme an understanding of the farmers, their farming situation, resources and rapport with them was established. Before the demonstration soil sampling was also collected and tested and found to be moderately acidic in texture with soil $\mathrm{pH}$ ranging from 5.5-6.0. The available nitrogen, phosphorus and potassium were also analyse and found to be 350-410, 12-45 and 124-156, respectively.

Estimation of yield increase over farmers practice, technological gap, extension gap and technological index

In Cluster Frontline Demonstration scientific package of practices were adopted whereas in farmers practices existing agricultural procedure followed by the farmers were taken. 
Primary data on farmers practices and crop yields were collected. The yield increase in demonstration over farmers' practice was calculated by using the following formula:

\% Yield Increase Over Farmers' Practice (\%YIOFP)

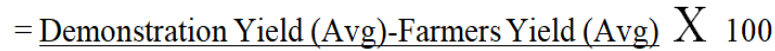
Farmers Yield (Avg)

The output data were analyzed as per Samui et al., (2000) to estimate the Technology gap, Extension gap and Technology index with the following equations.

Technology gap $=$ Potential yield Demonstration yield (avg)

Extension gap $=$ Demonstration yield (avg) Farmers yield (avg)

Technology Index $=$ Potential yield - Demonstrationyield (avg) $X 100$

\section{Economic analysis of the demonstration}

Cost of cultivation includes all expenses for purchase of seeds, pesticides, labour cost and other operational charges that could have incurred during the production process. The farmers' family labour was not taken into consideration for the present study. The Gross return and Net return were worked out accordingly by taking cost of cultivation and price of grain yield in each case of the oilseed crop.

Additional cost was worked out to analyse the overall expenditure on the improved technology over farmers practice. Similarly the Incremental Benefit cost ratio (IBCR) was worked out as a ratio of additional returns and corresponding additional costs as presented by Vedna et al., 2007.

\section{Results and Discussion}

\section{Grain yield}

Demonstrated yield data (Table 1) revealed that the yield of oilseed fluctuated between the years and were invariably higher than the farmer's yield. On average the demonstrated yield was highest in groundnut $(894 \mathrm{~kg} / \mathrm{ha})$ and lowest in sesamum $(532.5 \mathrm{~kg} / \mathrm{ha})$ as similar trend follows in case of farmers yield with an average high in groundnut (738 $\mathrm{kg} / \mathrm{ha}$ ) and lowest for sesamum (446.5 kg/ha).

The percentages yield increase of demonstration over farmers yield was also observed in groundnut with highest $(27.85 \%)$ during kharif 2018 and lowest (15.07\%) during the previous year of kharif 2017, with highest (21.46\%) average yield increase among the oilseed crops.

The data also indicated that the yield could be raised to 15.38 to 22.8 percent in toria (TS$36), 15.07$ to 27.85 percent in groundnut (G2) and 17.77 to 20.76 percent in sesamum (ST-1683) over farmers yield by adoption of improved oilseeds technology.

\section{Yield gaps analysis}

The yield under demonstrations, potential yield and farmers yield were compared to assess the yield gaps of the technology. The yield gap was categorized into extension and technology gap. Extension gap indicates the need to motivate farmers to adopt improved technologies over the local practices.

The maximum extension gap in groundnut (195 kg/ha) during kharif 2018 and kharif $2017(117 \mathrm{~kg} / \mathrm{ha})$ was observed to be the highest with an average extension gap of 156 $\mathrm{kg} / \mathrm{ha}$, it also indicated to be the highest on average basis among the oilseeds. 
The lowest extension gap average of 19.09 $\mathrm{kg} / \mathrm{ha}$ was observed in toria with extension gap of $130 \mathrm{~kg} / \mathrm{ha}$ and $100 \mathrm{~kg} / \mathrm{ha}$ during rabi 2018-19 and rabi 2017-18, respectively. Technology gap was the highest in groundnut $(807 \mathrm{~kg} / \mathrm{ha}$ and $805 \mathrm{~kg} / \mathrm{ha})$ during kharif 2017 and kharif 2018 while it was lowest in sesamum (270 kg/ha and $265 \mathrm{~kg} / \mathrm{ha})$ during the same growing period of kharif 2017 and kharif 2018, on average the highest technology gap was observed in groundnut $(806 \mathrm{~kg} / \mathrm{ha})$ followed by toria $(475 \mathrm{~kg} / \mathrm{ha})$ while the lowest gap was indicated in sesamum (267.5 kg/ha).

The observed technology gap was mainly due to soil nutrient status differences, rainfed condition and hilly terrain prevailing in the district. Though potential yield of a crop in normal locale condition is difficult to be achieved yet, the technology gap can be minimized only if better performing varieties are available.

Therefore, it is suggested the need of better performing genotypes for improving the productivity of higher altitudes. Similar suggestion had also been proposed in earlier studies by Bhatia et al., (2006), Bhartiya et al., (2017).

Although, demonstration are conducted under strict supervision of the scientist, technology gap appears which may be attributed mainly due to lack of irrigation facilities, variation in soil fertility status, non-congenial weather conditions and local specific management problems faced for the attainment of potential and demonstration yields (Kanojia et al., 2019).

\section{Technology index}

Technology index indicates the feasibility of the evolved technology in the farmers' field. Lower the value of technology index, higher is the feasibility of the improved technology (Balai et al., 2013). Technology index during the period of study on average basis varied from 33.43 percent to 47.41 Percent.

The lowest technology index was recorded in sesamum var. ST-1683 (33.12\%) during kharif 2017 while highest value of $47.47 \%$ was observed in groundnut var. G-2 during kharif 2017.

Technology index was higher in groundnut (47.35 to $47.47 \%$.) as compared to toria (37.5 to $41.6 \%$ ) and sesamum (33.12 to $33.75 \%$ ). This indicates that a wide gap existed before the technology evolved and technology adoption at the farmers' field.

\section{Economic analysis}

The Economic analysis (Table 2) of Gross and Net returns on average basis was observed to be highest (Rs. 43806/ha \& Rs. 24946/ha) in groundnut var.G-2 under demonstration as well as the farmers' yield (Rs. 36162/ha \& Rs. 19127/ha).

Similar, trend on average basis was also followed in terms of lowest Gross and Net returns as it was observed under demonstration (Rs. 25440/ha \& Rs. 11440/ha) and farmers yield (Rs. 21600/ha \& Rs. $8500 /$ ha) in case of sesamum.

The additional cost of production of improved technology on average basis varied between Rs.950/ha and Rs.1825/ha with the highest expenditure in groundnut, followed by toria (Rs. 1350/ha) and lowest in sesamum.

The additional return on average also followed a similar trend with maximum return of Rs.5819/ha in case of groundnut, followed by toria (Rs.3430/ha) and lowest return of Rs. $3178 /$ ha in sesamum. 
Table.1 Technology gap, Extension gap and Technology index in oilseed production under Kohima District

\begin{tabular}{|c|c|c|c|c|c|c|c|c|c|c|c|}
\hline \multirow{3}{*}{$\begin{array}{l}\text { Crop/ } \\
\text { variety }\end{array}$} & \multirow{3}{*}{$\begin{array}{l}\text { Season/ } \\
\text { year }\end{array}$} & \multirow{3}{*}{$\begin{array}{l}\text { Area } \\
\text { (ha) }\end{array}$} & \multirow{3}{*}{$\begin{array}{l}\text { No. of } \\
\text { farmers }\end{array}$} & \multirow{3}{*}{$\begin{array}{l}\text { No. of } \\
\text { villages }\end{array}$} & \multirow{2}{*}{\multicolumn{3}{|c|}{ Yield (kg/ha) }} & \multirow{3}{*}{$\begin{array}{c}\text { Increase } \\
\text { in yield } \\
(\%)\end{array}$} & \multicolumn{2}{|c|}{ Gap analysis (kg/ha) } & \multirow{3}{*}{$\begin{array}{l}\text { Technology } \\
\text { Index } \\
(\%)\end{array}$} \\
\hline & & & & & & & & & Extension gap & Technology & \\
\hline & & & & & PY* & DY* & FY* & & & gap & \\
\hline \multicolumn{12}{|l|}{ Toria } \\
\hline TS-36 & Rabi 2017-18 & 20 & 38 & 7 & 1200 & 750 & 650 & 15.38 & 100 & 450 & 37.5 \\
\hline TS-36 & Rabi 2018-19 & 10 & 25 & 5 & 1200 & 700 & 570 & 22.80 & 130 & 500 & 41.6 \\
\hline Average & & 15 & 31.5 & 6 & 1200 & 725 & 610 & 19.09 & 115 & 475 & 39.55 \\
\hline \multicolumn{12}{|l|}{ Groundnut } \\
\hline G-2 & Kharif 2017 & 20 & 23 & 6 & 1700 & 893 & 776 & 15.07 & 117 & 807 & 47.47 \\
\hline G-2 & Kharif 2018 & 20 & 33 & 11 & 1700 & 895 & 700 & 27.85 & 195 & 805 & 47.35 \\
\hline Average & & 20 & 28 & 8.5 & 1700 & 894 & 738 & 21.46 & 156 & 806 & 47.41 \\
\hline \multicolumn{12}{|l|}{ Sesamum } \\
\hline ST-1683 & Kharif 2017 & 20 & 19 & 8 & 800 & 535 & 443 & 20.76 & 92 & 265 & 33.12 \\
\hline ST-1683 & Kharif 2018 & 20 & 20 & 9 & 800 & 530 & 450 & 17.77 & 80 & 270 & 33.75 \\
\hline Average & & 20 & 19.5 & 8.5 & 800 & 532.5 & 446.5 & 19.26 & 172 & 267.5 & 33.43 \\
\hline
\end{tabular}

*PY-Potential Yield, DY-Demonstration Yield, FY-Farmers Yield

Table.2 Economic analysis of CFLD in oilseed production under Kohima District

\begin{tabular}{|c|c|c|c|c|c|c|c|c|c|c|}
\hline \multirow[t]{2}{*}{$\begin{array}{l}\text { Crop/ } \\
\text { variety }\end{array}$} & \multirow[t]{2}{*}{$\begin{array}{l}\text { Season/ } \\
\text { year }\end{array}$} & \multicolumn{2}{|c|}{$\begin{array}{c}\text { Cost of cultivation } \\
\text { (Rs/ha) }\end{array}$} & \multicolumn{2}{|c|}{$\begin{array}{l}\text { Gross return } \\
\quad(\mathrm{Rs} / \mathrm{ha})\end{array}$} & \multicolumn{2}{|c|}{$\begin{array}{l}\text { Net Return } \\
\quad(\text { Rs/ha) }\end{array}$} & \multirow[t]{2}{*}{$\begin{array}{l}\text { Additional cost } \\
\qquad(\mathrm{Rs} / \mathrm{ha})\end{array}$} & \multirow{2}{*}{$\begin{array}{l}\text { Additional } \\
\text { return } \\
(\mathrm{Rs} / \mathrm{ha})\end{array}$} & \multirow[t]{2}{*}{ IBCR* } \\
\hline & & DY & $\mathrm{FY}$ & DY & FY & DY & $\mathrm{FY}$ & & & \\
\hline \multicolumn{11}{|l|}{ Toria } \\
\hline TS-36 & Rabi 2017-18 & 14150 & 12950 & 30750 & 26650 & 16600 & 13700 & 1200 & 2900 & 2.42 \\
\hline TS-36 & Rabi 2018-19 & 14750 & 13250 & 29400 & 23940 & 14650 & 10690 & 1500 & 3960 & 2.64 \\
\hline Average & & 14450 & 13100 & 30075 & 25295 & 15625 & 12195 & 1350 & 3430 & 2.53 \\
\hline \multicolumn{11}{|l|}{ Groundnut } \\
\hline G-2 & Kharif 2017 & 18860 & 17500 & 43757 & 38024 & 24897 & 20524 & 1360 & 4373 & 3.21 \\
\hline G-2 & Kharif 2018 & 18860 & 16570 & 43855 & 34300 & 24995 & 17730 & 2290 & 7265 & 3.17 \\
\hline Average & & 18860 & 17035 & 43806 & 36162 & 24946 & 19127 & 1825 & 5819 & 3.19 \\
\hline \multicolumn{11}{|l|}{ Sesamum } \\
\hline ST-1683 & Kharif 2017 & 14050 & 13050 & 25680 & 21264 & 11630 & 8214 & 1000 & 3416 & 3.41 \\
\hline ST-1683 & Kharif 2018 & 14000 & 13100 & 25440 & 21600 & 11440 & 8500 & 900 & 2940 & 3.26 \\
\hline Average & & 14025 & 13075 & 25560 & 21432 & 11535 & 8357 & 950 & 3178 & 3.33 \\
\hline
\end{tabular}

*IBCR- Incremental Benefit Cost Ratio 
Incremental Benefit Cost Ratio (IBCR) on average also varied between 2.53 and 3.33 among the different oilseed crops. The highest IBCR of 3.41 and 3.26 was recorded in case of sesamum (ST-1683) during both the years followed by groundnut (3.21) during kharif 2017. The lowest IBCR of 2.42 was recorded in case of toria var. TS-36 during Rabi 2017-18.

From the data collected during the study period, it was found that exist a wide gap between potential and demonstration yield mainly due to Technology and Extension gap.

It can also be concluded that the oilseed productivity can be improved by adopting the improved Technologies by changing the farmers' attitude towards newer technology and willingness to try new production techniques.

\section{Acknowledgement}

We are thankful to Director ATARI, NER Zone-VII, umiam Meghalaya for sponsoring the project under NFSM Oilseed programme and also those beneficiaries who devoted their time and energy for the purpose of technology demonstration and adoption.

\section{References}

Anonymous (2008)- Vision 2020: Krishi Vigyan Kendra, Nagaland. pp 95. GoI, Annual Report (2018-19), Deptt. of Agriculture, Cooperation \& Farmers Welfare, New Delhi.

Balai C.M., Jalwania R., Verma L.N., Bairwa R.K. and Regar P.C. (2013) Economic impact of front line demonstrations on vegetables in tribal belt of Rajasthan. Curr. Agri. Res. 1(2): 69-77.
Bhartiya. A, N. Chandra, R.S. Pal, J.P. Aditya and Jyoti Bajeli. (2017). Comparative yield gaps, economic impact and constraint analysis in front line demonstrations of soybean and black soybean in Uttarakhand hills. Indian J. Agric. Res. 51(5): 483-487

Bhatia V.S., Singh P., Wani S.P, Kesava Rao A. V. R and Srinivas K.(2006). Gap analysis of soybean, groundnut, pugeon pea and chicj pea in India using simulation modeling. Global theme on Agroecosystems Report. International crops Research Institute for Semi-arid Tropics (ICRISAT): (156)

Kanojia Yogesh, singh harish Chandra and Damor, R.K. (2019). Yield gap analysis of soybean through Frontline demonstration in pratapgarh: A tribal district of Rajasthan, India. Int. Jn Curr. Microbial App. Sci. 8 (04): 1020-1023.

Mubark. T and Shakoor, A. (2019) Impact Assessment of Technological Interventions for Reducing Yield Gaps in Rice (Oryza sativa L.) Under Temperate Hill Ecology. Journal of Krishi Vigyan 7 (2) : 140-143

Pongen. L.Y., Imtisenla and Zhimomi V. A. (2019) Impact Assessment in Yield Gaps of Cluster Front Line Demonstration under Pulse Production in Kohima District. International Journal of Agriculture Sciences, 11(15): 8883-8884.

Samui S.K., Maitra S., Roy D.K., Mandal A.K. and Saha D. (2000) Evaluation of front line demonstration on groundnut. J. Indian Soc .Coastal Agric. Res. 18(2): 180-183.

Vedna, Kumari, Kumar, A., Kumar, A. and Bhateria, S. (2007) Demonstration - an effective tool for increasing the productivity of rapeseed- mustard in Kangra district of Himachal Pradesh. Himachal Journal of Agricultural Research 33(2): 257-261.

\section{How to cite this article:}

Imtisenla, Longma Yanger Pongen, Temjennungsang, Khekali Sema, K. Michael Pienyu, Zhiete and Akashe Zhimomi, V. 2020. Oilseeds Production Gaps under Cluster Frontline Demonstration in Kohima District of Nagaland, India. Int.J.Curr.Microbiol.App.Sci. 9(05): 2023-2028. doi: https://doi.org/10.20546/ijcmas.2020.905.229 